\title{
Metsästä on puhuttava ja kirjoitettava
}

Koronavuosi on ollut suuri ulkoiluvuosi. Metsäpolut, luonnonpuistot ja hiihtoladut täyttyvät ihmisistä, osin siksi, että muuallekaan ei voi mennä. Tarvitsemme metsää pysyäksemme järjissämme, mutta toisaalta silloin kun muutakin oli tarjolla, emme menneet metsiin ruuhkaksi asti. Tuntuu, että poikkeusaika on tehnyt näkyväksi jotakin oleellista metsäsuhteestamme: luotamme siihen, että metsä on, odottaa rauhallisena ja vankkumattomana ja auttaa meitä tiukan paikan tullen; muun ajan voimme oikeastaan olla ajattelematta sitä.

Metsiin liittyvät käsitykset ja esitykset, erilaiset metsien käytön tavat ja niihin liittyvät monimutkaiset sosiaaliset suhteet ja aineelliset käytännöt torpparijärjestelmästä tervanpolttoon ja tervakapitalismiin, tieteelliset kiistat metsänkasvatuksesta, metsäluonnonvarojen riittävyydestä ja hiilinielujen toiminnasta metsälajien monimuotoisuuteen talousmetsissä ja luonnonvaraisissa metsissä - tässä vain maistiaisia kamppailuista, joita metsiin suomalaisessa kulttuurissa liittyy. Tämä erikoisnumero kartoittaa sitä, millaisena metsä näkyy suomalaisen kirjallisuudentutkimuksen kentällä tänään. Ekokriittiset, posthumanistiset ja uusmaterialistiset lähestymistavat ovat tehneet metsistä uudella tavalla kiinnostavan kysymyksen humanisteillekin. Inhimillistä ja ei-inhimillistä tarkastellaan toisiinsa limittyneinä ja toisiinsa vaikuttavina, eikä metsäaiheista kirjallisuutta tarvitse lukea vain kulttuuristen merkitysten ilmentymänä.

Kirjallisuustieteellinen metsäkeskustelu on osa viime vuosina versonutta laajempaa metsiin, metsien käyttöön ja metsäsuhteisiin liittyvää yhteiskuntatieteellistä ja humanistista tutkimusta. Metsiä koskevalla ympäristö- ja taloushistoriallisella tutkimuksella on toki pitkät perinteet Suomessa. Nykyisin puhutaan kuitenkin entistä useammin metsien kulttuurisista arvoista ja merkityksistä. Eri ihmisryhmien metsäsuhteita sekä metsienkäytön ja metsäkulttuurien historiaa tarkastellaan erilaisin laadullisin menetelmin. Metsistä kiinnostuneelle kirjallisuudentutkijalle tämä tarkoittaa runsaasti kiinnostavaa lähdemateriaalia, uusia lähestymistapoja ja käsitteitä.

Kuitenkin kaunokirjallisuuden ja kirjallisuudentutkimuksen metsät ovat myös oma kysymyksensä. Kirjallisuuden metsät ovat fiktiivisiä ja tekstuaalisia ympäristöjä, joiden luomista, tutkimista ja tulkintaa ohjaavat kyllä fyysiset metsät luontokulttuurisine käytön ja käytäntöjen ulottuvuuksineen, mutta jotka myös taipuvat ja kasvavat kohti sitä, mitä voisi olla tai mitä voisi tulla olemaan ollut. Kirjallisuuden ja sen tutkimuksen metsät ovat myös väyliä katsoa muualle. Tämän numeron artikkeleissa metsät tarjoavat käsitteellisen 
ja kokemuksellisen alueen ajatella uusiksi historiaan ja luontosuhteisiin liittyviä kysymyksiä: järjestykseen asettuvan kansalaisuuden sosiaalisia ehtoja, suullisen kansanperinteen tallentumista ja tulkintaa sekä metsässä avautuvaa kokemushorisonttien moninaisuutta. Lehden ensimmäisessä artikkelissa Kaisa Kurikka lukee Johanna Holmströmin teosta Camera Obscura ja analysoi tapoja, joilla metsien merkitykset kerrostuvat kaunokirjallisessa ilmaisussa, palautumatta suoraan mihinkään itsensä ulkopuoliseen. Kurikan lähtökohdat ovat Gilles Deleuzen ja Félix Guattarin filosofiassa ja nykykirjallisuuden tulkinnassa. Toisessa artikkelissa Tiina Seppä puolestaan osoittaa, millaista tietoa teollistumista edeltävästä suomalaisesta luontosuhteesta saadaan, kun kansanrunoutta luetaan posthumanistisessa kehyksessä. Seppää kiinnostaa erityisesti metsän toimijuus Suomen Kansan Vanhoissa Runoissa. Lehden kolmannessa artikkelissa Niina Hämäläinen tarkastelee inhimillistä toimijuutta samalla ajanjaksolla: hän analysoi Elias Lönnrotin kansanrunojen pohjalta koostamaa Kanteletarta ja osoittaa, kuinka vahvasti Lönnrotin valinnat ovat vaikuttaneet Kantelettaressa ilmenevään luontokuvastoon ja siten käsityksiimme siitä, millaisia luontokäsityksiä kansanrunous sisältää. Artikkeliosuuden päättää Elsi Hyttinen, joka tarkastelee 1910-luvun kirjallisuuden erämetsiä ja sitä, miten niiden kuvauksissa on kyse sekä kansakunnan luontosuhteen että seksuaalisen järjestyksen artikuloimisesta.

Metsien rinnalla numeron kirjoituksissa käsitellään ei-inhimillisiä koskevaa tutkimusta yleisemminkin. Kaisa Kortekallio, Mariia Niskavaara, Hannah Ouramo, Juha Raipola, Tarja Salmela, Ate Tervonen ja Sanna Karkulehto esittelevät esseessään ehdotuksia posthumanistisen tutkimuksen keskeisten käsitteiden suomennoksiksi. Metsäisemmässä esseessä Ate Tervonen tarkastelee Suomen metsien nykytilaa omien valokuvin dokumentoitujen havaintojensa perusteella ja sosiaalisen median kuvavirrassa. Karoliina Lummaan essee paikallistuu Hyytiälän metsäntutkimusasemalle ja käsittelee taiteellisen ja tieteellisen metsistä tietämisen yhteyksiä nykyrunoudessa ja ympäristötieteessä. Kirja-arvioissa esitellään luontosuhteiden tutkimuksen kannalta kiinnostavia ja ajankohtaisia teoksia. Veli-Matti Pynttäri arvioi kaksi nykyihmisen luontosuhdetta jäsentelevää esseekokoelmaa, Pauliina Haasjoen Himmeän sinisen pisteen (2019) ja Riikka Kaihovaaran Villin ihmisen (2019). Jouni Teittinen arvioi Sanna Karkulehdon, Aino-Kaisa Koistisen ja Essi Variksen toimittaman teoksen Reconfiguring Human, Nonhuman and Posthuman in Literature and Culture (2020).

Tätä numeroa viimeisteltäessä lumi on pitkästä aikaa peittänyt koko Suomen. On helpottavaa, kun metsät näyttävät siltä, kuin niiden tammikuussa pitäisikin näyttää. Talvisilta. Ilmastonmuutosta ei kuitenkaan ole peruutettu, ja tyynnyttävänä tuiskuava lumi saa osan voimastaan liian lämpimänä 
höyryävästä Itämerestä. Toistaiseksi vielä metsät odottavat meitä, mutta kaikki muuttuu. Siksikin metsästä on puhuttava ja kirjoitettava. Jotta muistamme, millainen se oli tänään ja miten tähän tultiin.

Elsi Hyttinen ja Karoliina Lummaa 